\title{
MENINGKATKAN KEMAMPUAN KOMUNIKASI MATEMATIS MENGGUNAKAN PENDEKATAN PENDIDIKAN MATEMATIKA REALISTIK INDONESIA (PMRI) DI SMK AL KARAMAH
}

\author{
Yundaryati $^{1}$, Suyoto ${ }^{2}$ \\ SMK Al Karamah ${ }^{1}$ \\ Program Studi PPG, Universitas Muhammadiyah Gresik ${ }^{2}$ \\ smkalkaramah@gmail.com
}

\begin{abstract}
Abstrak
Kemampuan komunikasi matematis diperlukan dalam memahami pelajaran yang diberikan oleh guru. Rendahnya kemampuan komunikasi matematis peserta didik SMK Al Karamah Jombang disebabkan karena peserta didik kurang diikutsertakan dalam pembelajaran atau peserta didik jarang diberikan kesempatan untuk bertanya maupun mengungkapakan pendapat. Pendekatan pembelajaran yang digunakan guru selama ini kurang tepat, sehingga kemampuan komunikasi matematis peserta didik belum mampu tersampaikan. Salah satu model pembelajaran yang cocok adalah pendekatan Pendidikan Matematika Realistik Indonesia (PMRI) untuk melihat apakah terdapat perbedaan pembelajaran tersebut dengan model pembelajaran konvensional terhadap peningkatan kemampuan komunikasi matematis ditinjau dari jenis kelamin peserta didik.

Jenis eksperimen yang digunakan dalam penelitian ini adalah Quasi Eksperimen Design menggunakan pretes dan postes. Populasi penelitian ini adalah peserta didik kelas XII SMK Al Karamah Jombang. Sampel yang digunakan sebanyak 1 kelas yang dipilih dengan teknik acak kelas, yaitu kelas XII SMK Al Karamah Jombang dengan pendekatan Pendidikan Matematika Realistik Indonesia (PMRI). Teknik pengumpulan data yang digunakan adalah tes. Analisis data yang digunakan adalah uji Kruskal-Wallis

Menurut hasil penelitian dan pembahasan, perhitungan dengan menggunakan uji Kruskal-Wallis, diperoleh nilai $\mathrm{H}=1,233<7,815$. Sehingga dapat diambil keputusan $\mathrm{Ho}$ dari hipotesis ini diterima, dengan kata lain bahwa Ha dari hipotesis yang diajukan ditolak maka dapat disimpulkan bahwa tidak terdapat perbedaan kemampuan komunikasi matematis yang menggunakan pendekatan pembelajaran Pendidikan Matematika Realistik Indonesia (PMRI) SMK Al Karamah Jombang Tahun Ajaran 2019/2020.
\end{abstract}

Kata kunci: Pendekatan Pendidikan Matematika Realistik Indonesia (PMRI), kemampuan komunikasi matematika

\begin{abstract}
Abstrack
Mathematical communication skills are needed in understanding the lessons given by the teacher. The low mathematical communication skills of students of Al Karamah Jombang Vocational School are caused by the lack of participation of students in learning or students are rarely given the opportunity to ask questions or express opinions. The learning approach used by the teacher so far is not right, so the mathematical communication skills of students have not been able to convey. One suitable learning model is the Indonesian Realistic Mathematics Education (PMRI) approach to see whether there is a difference in learning with conventional learning models to improve mathematical communication skills in terms of the sex of students.

The type of experiment used in this research is Quasi Experiment Design using pretest and posttest. The population of this study was students of class XII Al Karamah Jombang Vocational School. The sample used was 1 class selected by random class technique, namely class XII Al Karamah Jombang Vocational School with the
\end{abstract}


Indonesian Realistic Mathematics Education (PMRI) approach. The data collection technique used is a test. Analysis of the data used is the Kruskal-Wallis test According to the results of research and discussion, calculations using the Kruskal-Wallis test, obtained a value of $H=1.233<7.815$. So that the decision Ho can be taken from this hypothesis is accepted, in other words that Ha of the proposed hypothesis is rejected, it can be concluded that there is no difference in mathematical communication skills using the learning approach of Indonesian Realistic Mathematics Education (PMRI) Al Karamah Jombang Vocational School Academic Year 2019/2020.

Keywords: Indonesian Realistic Mathematics Education Approach (PMRI), mathematical communication skills

\section{PENDAHULUAN}

Upaya meningkatkan kualitas pendidikan matematika masih menghadapi berbagai permasalahan, di antaranya masih banyak konsep dalam matematika yang belum dikuasai siswa sehingga ada sebagian anak didik yang menganggap bahwa pelajaran matematika merupakan pelajaran yang menakutkan dan membosankan. Akibatnya berpengaruh terhadap sikap siswa yang kurang antusias terhadap mata pelajaran matematika.

Hal ini terjadi pada siswa di SMK AL KARAMAH Peterongan Jombang. Siswa kurang memahami perhitungan dari materi yang disampaikan guru, serta guru hanya menyampaikan materi secara konvensional kepada siswa. Sehingga siswa mengalami kesulitan dalam memahami dan menyelesaikan soal-soal yang diberikan guru. Siswa pun hanya bermain dan kurang memperhatikan guru pada saat mengajar dikelas. Hal ini berarti komunikasi hanya terjadi satu arah saja yaitu dari guru ke murid tanpa adanya timbal balik.

Kemampuan komunikasi matematis merupakan kemampuan siswa dalam menggunakan matematika sebagai alat komunikasi (bahasa matematika), dan kemampuan siswa dalam mengkomunikasikan matematika yang dipelajarinya sebagai isi pesan yang harus disampaikan. Menurut Kennedy dan Tipps (1994) kemampuan komunikasi matematika meliputi penggunaan bahasa matematika yang disajikan dalam bentuk lisan, tulisan, atau visual; (2) penggunaan representasi matematika yang disajikan dalam bentuk tulisan atau visual; dan (3) penginterpretasian ide-ide matematika, menggunakan istilah atau notasi matematika dalam merepresentasikan ide-ide matematika, serta menggambarkan hubungan-hubungan atau model matematika.

Akan tetapi berdasarkan hasil yang dilakukan oleh peneliti terhadap guru mata pelajaran matematika SMK AL KARAMAH bahwa hingga saat ini hasil belajar pelajaran khususnya matematika masih dikatakan rendah jika dibandingkan Kriteria Ketuntasan Minimal (KKM) yang telah ditetapkan 75. Faktor-faktor yang mempengaruhi siswa mengalami kesulitan dalam belajar adalah siswa kurang menganalisis soal, kurang membaca, dan memahami soal secara seksama. Mereka akan lebih senang bermain daripada belajar. Siswa akan lebih cepat mengerti materi apabila guru memberikan contoh di 
dalam kehidupan sehari-hari, tetapi siswa masih kesulitan dalam menyelesaikan soal terkait menuliskan masalah kehidupan seharihari ke dalam bentuk model matematika.

Salah satu kemampuan yang harus dimiiki siswa dalam pelajaran matematika adalah kemampuan dalam berkomunikasi. Karena matematika merupakan proses sosial dimana mereka harus berinteraksi, bekerja sama, dan berkomunikasi antara siswa yang satu dengan yang lainnya serta dengan pendidiknya. Jadi dapat dikatakan bahwa kemampuan komunikasi matematis merupakan kemampuan siswa dalam menggunakan matematika sebagai alat komunikasi (bahasa matematika), serta kemampuan siswa dalam mengkomunikasikan matematika yang dipelajarinya sebagai isi pesan yang harus disampaikan. Proses komunikasi dalam pembelajaran di kelas terjadi apabila siswa bersifat responsif, aktif bertanya dan menanggapi permasalahan yang ada, serta mampu menuangkan kedua permasalahan tersebut secara lisan maupun tertulis.

Berdasarkan indikator kemampuan komunikasi matematis yang dikutip oleh Fachrurazi (2011) yaitu

1) Menulis matematika, kemampuan menuliskan penjelasan dari jawaban permasalahannya secara matematika, masuk akal, jelas serta tersusun secara logis; 2) Menggambar secara matematika, kemampuan untuk dapat menuliskan gambar, diagram, tabel secara lengkap dan benar; serta 3) Ekspresi matematika, kemampuan untuk dapat memodelkan permasalahan secara benar, kemudian melakukan perhitungan atau mendapatkan solusi secara lengkap dan benar.

Berdasarkan indikator diatas bahwa kemampuan komunikasi dalam pembelajaran matematika itu sangat penting dalam. Melalui komunikasi, siswa dapat menyampaikan ideidenya kepada guru dan kepada siswa lainnya. Komunikasi matematis bisa berlangsung antara guru dengan peserta didik, antara buku dengan peserta didik, dan antar peserta didik dengan peserta didik. Setiap kali mengkomunikasikan gagasan-gagasan matematika peserta didik harus menyajikan gagasan tersebut dengan suatu cara tertentu. Peserta didik dalam belajari matematika seakan-akan mereka berbicara dan menulis tentang apa yang sedang mereka kerjakan. Salah satu upaya untuk meningkatkan kemampuan komunikasi matematis siswa adalah dengan menggunakan pendekatan Pendidikan Metematika Realistik Indonesia (PMRI).

Pendidikan Matematika Realistik adalah suatu strategi pembelajaran yang menggunakan masalah realistik sebagai awal dari pembelajaran matematika agar terampil dalam memecahkan masalah, sehingga mereka memperoleh pengetahuan dan konsep-konsep yang esensial dari materi pembelajaran. Pendekatan PMRI lebih memusatkan kegiatan pembelajaran pada siswa dan lingkungan. Pendekatan PMRI tidak terlepas dari kehidupan dunia nyata. Dalam proses pembelajaran dengan pendekatan ini, guru tidak langsung memberikan rumus atau konsep kepada siswa, tetapi terlebih dahulu guru memberikan pengantar berupa penyajian suatu 
bentuk cerita yang dekat dengan kehidupan siswa, kemudian membimbing siswa untuk menentukan kembali dan mengkontruksi sendiri konsep matematika dari permasalahan yang diberikan. Disini siswa dialihkan untuk lebih aktif mengkontruksi atau membangun sendiri konsep yang akan diperolehnya karena terlibat langsung ke dunia nyata.

Pendekatan PMRI juga merupakan salah satu pendekatan yang sangat baik digunakan dalam upaya meningkatkan kemampuan komunikasi siswa. Treffers dalam Wijaya (2012: 21) merumuskan lima karakteristik PMRI yaitu: penggunaan konteks, penggunaan model untuk matematisasi progresif, pemanfaatan hasil konstruksi peserta didik, interaktivitas, dan keterkaitan. Seperti penelitian yang dilakukan Komang Agus Artawan, I Gusti Ngurah Japa, dan I Made Suarjana dalam Penerapan pendekatan PMRI bahwa dapat meningkatkan hasil belajar siswa dalam pembelajaran matematika siswa kelas XII SMK Al Karamah Peterongan Jombang.

Hal ini sesuai dengan tiga prinsip yang dimiliki PMRI yaitu 1) Penemuan (kembali) secara terbimbing (guided reinvention), melalui topik-topik matematika yang disajikan, siswa diberi kesempatan untuk mengalami proses yang sama dengan proses yang dilalui oleh para pakar matematika ketika menemukan konsep-konsep matematika; 2) Fenomena Didaktik (didactical phenomenology), topik-topik matematika yang diajarkan mesti dikaitkan dengan fenomena sehari-hari; dan 3) Pemodelan (emerging models), melalui pembelajaran dengan pendekatan matematika realistik, siswa mengembangkan model mereka sendiri sewaktu memecahkan.

Pada siklus I menunjukkan hasil belajar siswa sebesar 56.52 sedangkan pada siklus II meningkat menjadi 70.43. Dengan adanya suatu pendekatan pembelajaran ini maka materi yang diberikan pendidik dapat tersampaikan secara optimal. Oleh sebab itu penulis mengambil judul "Upaya Meningkatkan Kemampuan Komunikasi Matematis Menggunakan Pendekatan Pendidikan Matematika Realistik pada materi statistik.

\section{METODE}

Jenis penelitian ini adalah Penelitian Tindakan Kelas (PTK). PTK yang dilaksanakan terhadap pembelajaran matematika bagi siswa kelas XII SMK Al Karamah Peterongan Jombang ini menggunakan konsep model dari Kemmis dan Mc.Taggart (1992) dengan tahapantahapan yaitu ; (1) Tahap perencanaan, (2) Tahap pelaksanaan, (3) Tahap observasi, (4) Tahap refleksi. Secara lebih rinci prosedur penelitian tindakan kelas pada setiap siklus dapat dijabarkan pada gambar sebagai berikut: 


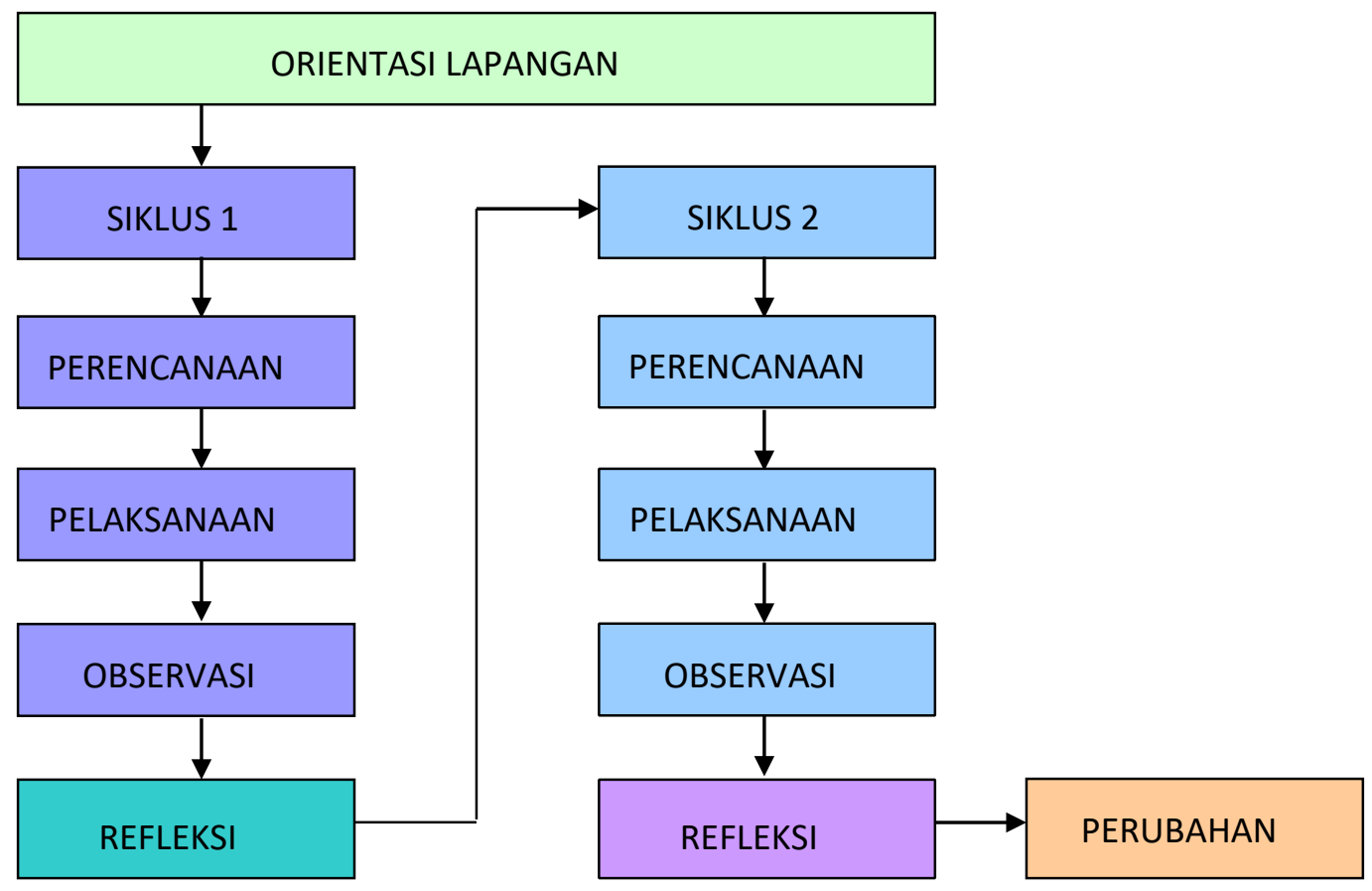

Sumber: Kemmis dan Mc.Taggart (1992)

\section{Gambar 1. Siklus Penelitian Tindakan Kelas}

Subyek penelitian ini adalah siswa kelas XII SMK Al Karamah Peterongan Jombang Tahun Pelajaran 2019-2020 yang berjumlah 24 orang. Tepat pelaksanaannya pada bulan Oktober sampai November 2019, pada semester ganjil. Faktor yang diteliti dalam penelitian ini adalah aktivitas siswa menggunakan alat peraga matematika selama pembelajaran berlangsung dan hasil belajar siswa dalam pelajaran matematika yaitu nilai akhir yang diperoleh dari tes akhir. Oleh karena itu untuk cara pengumpulan data penelitian ini, peneliti dengan menggunakan lembar observasi untuk aktivitas siswa selama mengikuti pembelajaran dan lembar tes untuk evaluasi soal-soal. Sementara untuk metode penelitiannya adalah memggunakan metode tes dan metode non tes (observasi).

Setelah data terkumpul terlebih dahulu data dianalisa secara kualitatif. Kemudian dalam mengambil kesimpulan menggunakan metode induktif. Metode induktif adalah metode yang berangkat dari fakta-fakta khusus, peristiwa-persitiwa konkrit, kemudian dari fakta-fakta / peristiwa yang khusus dan konkrit itu ditarik kesimpulan yang memiliki sifat umum.

Adapun pelaksanaan tindakan dalam penelitian ini akan dilaksanakan sesuai dengan rencana yang telah disusun oleh peneliti yakni dalam 2 siklus, sebagai berikut:

Siklus I. Siklus pertama ini dilaksanakan sesuai rencana, dengan kompetensi dasar 
4.2. yaitu menyelesaikan masalah yang berkaitan dengan statistika. Pada siklus ini dilakukan dengan penggunaan alat peraga Matematika. Kegiatan yang dilakukan:

a. Kegiatan Awal : Melakukan tanya jawab dengan guru mengenai materi.

b. Kegiatan Inti : Siswa melakukan diskusi kelompok dengan

mengerjakan lembar kerja siswa menggunakan alat peraga setelah itu mempresentasikan hasil diskusi kelompok masing-masing serta mengumpulkan hasil diskusi.

c. Kegiatan Akhir : Membuat rangkuman materi yang telah didapat dari praktek dan mengerjakan tes akhir.

Siklus II. Tahap ini siklus kedua merupakan perbaikan dari siklus I. Pada siklus ini tetap menggunakan alat peraga, dengan kompetensi dasar 4.2. yakni menyelesaikan masalah yang berkaitan dengan statistik. Kegiatan ini dilakukan tidak jauh beda dari siklus I yaitu melakukan proses pembelajaran sesuai indikator yang telah ditentukan tentang belajar Matematika menggunakan alat peraga. Kegiatan yang dilakukan meliputi:

a. Kegiatan Awal : Memberi tes awal, penyampaian tujuan pembelajaran

Matematika, mengaitkan pembelajaran dalam pengetahuan siswa.

b. Kegiatan Inti : Mengelompokkan siswa dalam beberapa kelompok dan memberi tugas kepada siswa dengan menggunakan alat peraga serta membimbing siswa untuk menggunakan alat peraga dan membuat kesimpulan akhir. c. Kegiatan Akhir : Membimbing siswa membuat rangkuman dari hasil diskusi.

Petunjuk-petunjuk yang diharapkan muncul sebagai wujud keberhasilan dalam melakukan tindakan pada penelitian ini antara lain adanya peningkatan aktivitas dan hasil belajar siswa serta prestasi belajar dengan hasil yang diperoleh mencapai KKM yang ditentukan yakni 5,8. Dengan ketercapaian $75 \%$ siswa yang mencapai KKM dari 24 siswa kelas IV. Hal ini ditunjukkan berdasarkan peningkatan rata-rata aktivitas siswa pada siklus I $(74,1 \%)$ menjadi $(79,4 \%)$ pada siklus II. Nilai rata-rata hasil belajar siswa mengalami peningkatan dari siklus I $(6,4)$ menjadi $(7,0)$ pada siklus II.

\section{HASIL DAN PEMBAHASAN}

Berdasarkan hasil penelitian yang telah dipaparkan di atas, peneliti memperoleh gambaran bahwa pelaksanaan pembelajaran dengan menerapkan kemampuan komunikasi matematika dengan menggunakan pendekatan matematika realistik. Dalam tes akhir siklus I, peneliti memberikan 2 jenis soal dengan jenis atau tingkat kesulitan yang 
berbeda, dengan maksud untuk mengetahui gambaran pemahaman dalam menyelesaikan soal yang jenisnya bervariasi. Hasilnya, diperoleh hasil bahwa dari dua nomor soal yang diberikan, semua siswa yang mengikuti tes dapat menyelesaikan soal dengan baik. menunjukkan bahwa untuk jenis soal ini, tidak mengalami masalah dalam menyelesaikannya soal fungsi, hal ini pula memberi arti bahwa taruni dapat memahami konsep statistika dengan sangat baik.

Aktivitas pembelajaran menggunakan kemampuan komunikasi matematika dengan menggunakan pendekatan matematika realistik, memberikan kesempatan seluruh taruni memiliki peran yang sama, yaitu aktifitas bertanya dan menjelaskan hingga saling memberikan pemahaman. Hasil yang diperoleh apabila dibandingkan dengan keadaan awal taruni menjawab dan menafsirkan soal fungsi dengan setelah taruni mengalami pembelajaran menggunakan menggunakan kemampuan komunikasi matematika dengan menggunakan pendekatan matematika realistik terdapat peningkatan signifikan.

Pada pelaksanaan siklus II, peneliti melakukan perbaikan-perbaikan dalam beberapa aspek kegiatan pembelajaran, penyajian materi, diskusi, interaksi personal serta dari segi pengelolaan waktu, menyadari bahwa suasana sosial yang dibuat di dalam kelas dan materi yang didiskusikan mempunyai pengaruh yang besar terhadap apa yang siswa pelajari dan sebaik apa pemahaman. Materi yang diajarkan pada siklus II adalah mengenai fungsi kuadrat. Hasil menunjukkan terjadi peningkatan aktivitas siswa dalam kegiatan pembelajaran ataupun mengkomunikasikan penyelesaian dalam kelompok. Berdasarkan pengamatan pada segi pelaksanaan pembelajaran pada siklus II, terlihat berlangsung lebih baik dan waktu yang digunakan lebih singkat.

Pelaksanaan tes akhir siklus II, peneliti pula memberikan 2 buah soal dengan jenis/tingkat kesulitan yang berbeda sebagaimana yang peneliti terapkan pada siklus I, dengan maksud untuk melihat sejauh apa kemampuan siswa dalam menyelesaikan soal-soal dengan jenis yang bervariasi.

Dari keseluruhan hasil serta pembahasan yang telah peneliti paparkan sebagaimana di atas, maka dapat dikatakan bahwa implementasi kemampuan komunikasi matematika dengan menggunakan pendekatan matematika realistik dalam kegiatan pembelajaran yang dilaksanakan dapat meningkatkan motivasi belajar dalam menyelesaikan soal statistika Kemampuan tersebut terutama dalam memahami masalah dan menuangkannya ke dalam grafik, sehingga 
dapat menjawab permasalahan sebagaimana yang peneliti ungkapkan dalam latar belakang.

\section{PENUTUP}

\section{Simpulan}

Berdasarkan hasil penelitian dan pembahasan, maka penelitian ini memberikan deskripsi sebagai berikut:

1. Implementasi kemampuan komunikasi matematika dengan menggunakan pendekatan matematika realistik dalam kegiatan pembelajaran pada materi konsep fungsi dapat meningkatkan motivasi belajar dan pemahaman.

2. Langkah-langkah pendekatan matematika realistik hanya dapat meningkatkan kemampuan siswa dalam menyelesaikan soal-soal cerita yang sederhana mengenai persamaan dan pertidaksamaan kuadrat, dan tidak demikian halnya untuk soal yang lebih kompleks yang melibatkan pengetahuan terhadap materi lain.

\section{Saran}

Sebelum menerapkan kemampuan komunikasi matematika dengan menggunakan pendekatan matematika realistik, perlu dipersiapkan secara matang hal-hal yang akan dilakukan terutama dari segi waktu, pemilihan soal serta dalam mengkombinasikannya dengan suatu model pembelajaran sehingga kegiatan belajar dapat berlangsung secara optimal.

\section{DAFTAR PUSTAKA}

Fachrurazi. 2011. Penerapan Pembelajaran Berbaris Masalah untuk Meningkatkan Kemampuan Berpikir Kritis dan Komunikasi Matematis Siswa Sekolah Dasar. Jurnal Edisi Khusus I, 81-87

Kemmis S dan Mc. Taggart. 1992. The Action Research Planner. Victoria: Deakrin University.

Kennedy, L.M. dan Tipps, S.. 1994. Guiding's Learning of Mathematics $\quad\left(7^{\text {th }} e d\right)$. California: Wadsworth.

Wijaya, A.. 201212. Pendidikan Matematika Realistik Suatu alternatif Pendekatan Pembelajaran Matematika. Yogyakarta: Graha Ilmu. 